\section{Birlesik Dunya Arastrma Cypriot Journal of Educational BD・CENTER \\ Innavasyon ve Yayıneılık Merkezi \\ Sciences}

Volume 16, Issue 6, (2021) 3394-3406

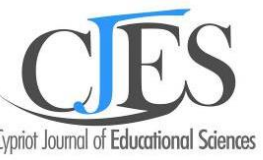

www.cjes.eu

\title{
The effect of mathematics self-efficacy on numeracy skills of prospective elementary school teachers
}

Yustitia Via *, Universitas Negeri Surabaya Ringgold standard institution, Mathematics education, Jalan dukuh menanggal 8A no 34 Gayungan Surabaya Gayungan Surabaya, Surabaya, West Java 60234, Indonesia / Universitas PGRI Adi Buana Surabaya Ringgold standard institution, Elementary education, Jalan dukuh menanggal 8A no 34 Gayungan Surabaya Gayungan Jalan dukuh menanggal 8A no 34 Gayungan Surabaya, Gayungan, Surabaya 60245, Indonesia

Siswono Tatag, Yuli Eko Siswono, Universitas Negeri Surabaya Ringgold standard institution - mathematics education, Surabaya, West Java, Indonesia

Abadi Abadi, Universitas Negeri Surabaya Ringgold standard institution - mathematics education, Surabaya, West Java, Indonesia

Suggested Citation:

Via, Y., Tatag, S., \& Abadi, A., (2021). The effect of mathematics self-efficacy on numeracy skills of prospective elementary school teachers. Cypriot Journal of Educational Science. 16(6), 3394-3406 https://doi.org/10.18844/cjes.v16i6.6590

Received from August 12, 2021; revised from October 11, 2020; accepted from December 17, 2021.

(C)2021 Birlesik Dunya Yenilik Arastirma ve Yayincilik Merkezi. All rights reserved

\begin{abstract}
Numeracy skills are the abilities to manage data and numbers to solve problems in various contexts of everyday life. However, numeracy skills of prospective elementary school teachers have not been satisfactory. One of the factors that influence numeracy skills is self-efficacy. Therefore, this study aims to investigate to what extent is the effect of self-efficacy on numeracy skills of prospective elementary school teachers. The type of this study was correlational research. In addition, the research population was prospective teachers in universities throughout Surabaya with a minimum accreditation of B for the bachelor's programme of elementary school teacher education. Furthermore, the samples were selected using proportional cluster random sampling, resulting in 293 prospective teachers or college students from the bachelor's programme of elementary school teacher education. Apart from that, the research instruments consisted of a numeration test and a self-efficacy questionnaire developed in a standardised manner. In addition, the applied analysis was a simple linear regression test with $r$ product moment. The results showed that (1) there was a positive relationship between self-efficacy and numeracy skills of prospective elementary school teachers and (2) the effect of self-efficacy on numeracy was $20.1 \%$. This indicated that $20.1 \%$ of the contribution to numeration skills of prospective elementary school teachers is influenced by self-efficacy, while the remaining $\mathbf{7 9 . 9 \%}$ is influenced by other factors not examined in this study. This study provides information on the characteristics and patterns of the relationship between self-efficacy and numeracy skills of elementary school teachers.
\end{abstract}

Keywords: Self-efficacy, numeracy skills, prospective elementary school.

\footnotetext{
* Address correspondence: Yustitia Via, Universitas Negeri Surabaya Ringgold standard institution, Mathematics education, Jalan dukuh menanggal 8A no 34 Gayungan Surabaya Gayungan Surabaya, Surabaya, West Java 60234, Indonesia Email address: via.18010@mhs.unesa.ac.id
} 
Via, Y., Tatag, S., \& Abadi, A., (2021). The effect of mathematics self-efficacy on numeracy skills of prospective elementary school teachers. Cypriot Journal of Educational Science. 16(6), 3394-3406 https://doi.org/10.18844/cjes.v16i6.6590

\section{Introduction}

Numeracy is the mathematical ability needed in the 21st century. Numeracy skills are the abilities to manage data and numbers to evaluate statements based on certain contexts (Cassen et al., 2018; Lange, 2003; Robson, 2010). In line with this, Steen (2003) argues that numeracy skills are related to the ability needed to interpret numbers, in which numbers play an important role in solving problems in everyday life, such as shopping or using public transportation. Numeracy is defined as the ability to access, use, interpret and communicate mathematical information and ideas in order to engage in and manage the mathematical demands for a range of situations in adult life (OECD, 2019). In addition, numeracy skills can train the ability to reason, interpret data and identify information (Sellars, 2018).

Furthermore, numeracy skills have an important role in developing the self-capacity of elementary school students in understanding the role of mathematics related to the concept of numbers to solve everyday problems (Ghazali, 2020; Millet et al., 2004; Robson, 2010). The importance of numeracy skills can be seen in the following example. A sophomore elementary school student learns the concept of multiplication of integers - three times two is six. The multiplication result is always the same even though the problem is replaced with two times three. However, the meaning will be different when it is given the context of taking medication. The rules of taking medicine three times two and two times three can have different meanings. Students who understand the concepts and have good numeracy skills will be able to explain the reasons for the different effects of drug absorption. Another example in a different situation is that a school will hold a farewell tour for class VI students. The participants are 118 people. If the capacity of the provided minibus is 35 people, then how to make the minibus cost more efficient? In this problem, students learn to realise that although the result of 118 divided by 35 is 3.37, for that purpose, it requires at least four minibuses. In this context, the concept of rounding numbers is not used. To make costs more efficient, the capacity of the fourth minibus must be chosen according to the needed seats and a minibus with a capacity of 35 should not be used.

Apart from that, studies on numeracy skills have been widely carried out. For example, a study conducted by Mahmud and Pratiwi (2019) indicated that the numeracy skills possessed by 34 grade IV students in Bandung concerning solving unstructured problems are not satisfactory. Those students had difficulty in making a settlement strategy. In addition, Nahdi et al. (2020) conducted a descriptive study on 60 prospective teachers at Majalengka University. The results showed that prospective teachers with high abilities may solve problems related to numeracy. Meanwhile, prospective teachers with moderate and low abilities did not show good performance. Furthermore, Callingham et al. (2015) carried out a case study in which the results indicated that teachers in remote areas of Tasmania did not recognise the complexity of numeracy. Therefore, they proposed the urgency of numeracy. Apart from that, a preliminary study conducted by researchers on 30 students of elementary school teacher education at UNIPA Surabaya indicated that the numeracy skills of those students were in the low category. Only $25 \%$ of them were able to answer the given questions correctly. The most obvious difficulty was analysing and making inferences regarding the given context. This phenomenon attracts researchers' attention to carry out further study. Prospective elementary school teachers with high ability can identify, find or access some mathematical information relevant 
Via, Y., Tatag, S., \& Abadi, A., (2021). The effect of mathematics self-efficacy on numeracy skills of prospective elementary school teachers. Cypriot Journal of Educational Science. 16(6), 3394-3406 https://doi.org/10.18844/cjes.v16i6.6590

to the purpose, involve using known mathematical procedures and rules and develop opinions about that information. However, there are some errors in communicating according to the content based on its interpretation results. Prospective elementary school teachers with low ability have been able to identify, find or access some mathematical information relevant to the goal. Still, they have not been able to involve procedures and develop opinions about the information (Yustitia et al., 2021).

Numeracy skills are not only a mathematical ability but also skills and confidence in handling and interpreting quantitative data. Apart from that, self-efficacy is an important factor in the process of solving mathematical problems (Tariq et al., 2013). Self-efficacy is one part of the social cognitive theory that affects someone's motivation and learning achievement (Garvis \& Pendergast, 2016). Self-efficacy may influence students in formulating information and interpreting mathematical problems (Arslan \& Yavuz, 2012; Ozgen, 2013; Zhu \& Chiu, 2019). Differences in self-efficacy between students may affect their learning outcomes. High selfefficacy may make students motivated to solve problems. In line with that, the results of a study conducted by Cheema (2018) show that there is a positive relationship between self-efficacy and mathematical literacy of secondary school students in Greece.

Besides, studies on teachers' self-efficacy have also been widely carried out. The results of several studies even indicate that teachers' self-efficacy may affect the success of students' learning process in secondary schools (Gerde et al., 2018; Maher et al., 2014; Skaalvik et al., 2015). Teachers' self-efficacy will affect the quality of the learning process, student success and personal satisfaction of the teacher itself. Self-efficacy can be considered one of the important factors that may be used as the basis for teachers' psychological success, including personal achievement, commitment to achievement and satisfaction with performance (Blomeke et al., 2020). However, there are no adequate reports on how much influence self-efficacy has on numeracy skills.

Therefore, this study is intended to provide more understanding of numeracy skills, specifically those concerning the government programme in improving the numeracy skills of elementary school students and to become a reference for solving problems of students and prospective teachers' difficulty in numeracy. Self-efficacy has been widely considered in various countries as a factor that determines the success of students in mastering the expected competencies. However, numeracy skills are still a new focus in the research of mathematics education.

Based on the elaboration aforementioned, the researchers conclude that there has been no study specifically revealing the characteristics and patterns of the relationship between numeracy skills and self-efficacy for prospective elementary school teachers. Therefore, this study aims to determine to what extent is the effect of self-efficacy on numeracy skills of prospective elementary school teachers.

\section{Methods}

\subsection{Research design}


This study was a quantitative correlational research. Furthermore, the type of method applied is ex post facto. In other words, researchers did not directly control the independent variable because the event had occurred (Creswell, 2012). Furthermore, the research design employed in this study is shown in Figure 1.

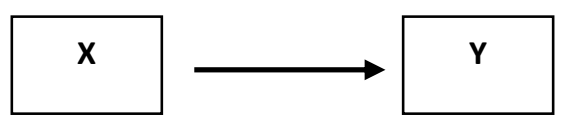

Figure 1. Research design

The variables in this study consisted of one independent variable, namely self-efficacy $(X)$, and one dependent variable, namely numeracy skills $(Y)$.

\subsection{Population and samples}

This study was conducted in the even semester of the 2020/2021 academic year from February to May 2021. The research population consisted of prospective teachers in universities throughout Surabaya with a minimum accreditation for the bachelor programme of elementary school teacher education. Furthermore, samples were selected using the proportional cluster random sampling. This technique allowed researchers to obtain a sample size that was proportional to the total population. Specifically, the total population in this study was 611 prospective elementary school teachers. After using the Slovin formula, the sample size for this study was 293 respondents, as shown in Table 1, for more detailed information.

Table 1. Distribution of the research population and samples

\begin{tabular}{llcc}
\hline No. & Universities & Population & Samples \\
\hline 1 & State University of Surabaya & 209 & 110 \\
2 & PGRI Adi Buana University of Surabaya & 245 & 106 \\
3 & Nahdatul Ulama University of Surabaya & 82 & 58 \\
4 & Muhammadiyah University of Surabaya & 75 & 19 \\
\hline & Total & 611 & 293 \\
\hline
\end{tabular}

\subsection{Instruments of data collection}

The data collection in this study was carried out using a questionnaire and a test. The questionnaire was used to obtain data concerning self-efficacy. Meanwhile, the test was used to obtain data concerning the numeracy skills possessed by prospective elementary school teachers. For this reason, the research instruments were a numeracy test and a mathematics self-efficacy questionnaire developed in a standardised manner. Therefore, the employed research instruments must be valid and reliable.

The numeracy test consisted of seven items in the form of essay questions developed by the researchers based on numeracy indicators. The validity of the test had been examined using logical validity, namely expert validity. The experts who examined the validity of this test were 
Via, Y., Tatag, S., \& Abadi, A., (2021). The effect of mathematics self-efficacy on numeracy skills of prospective elementary school teachers. Cypriot Journal of Educational Science. 16(6), 3394-3406 https://doi.org/10.18844/cjes.v16i6.6590

two mathematics education lecturers and one language lecturer. In addition to using the logical validity test, this test was also verified for empirical validity by trailing this test on batch 2018 students, totalling 83 participants. To measure the validity of this test, the researchers employed the product-moment correlation technique by utilising Statistical Package for the Social Sciences (SPSS) 23.0 software. This numeracy test is declared valid if the value of the correlation coefficient is greater than the value of the $r$-table. Meanwhile, in examining the reliability of this test, researchers applied Cronbach's alpha by utilising SPSS 23.0 software. If the value of Cronbach's alpha is $>0.60$, the numeracy test can be declared reliable. The results of the product-moment correlation indicated that seven items were valid, while the result of Cronbach's alpha analysis indicated a score of 0.610 . Therefore, the numeracy test was considered a valid and reliable instrument.

In this study, researchers also utilised the mathematics self-efficacy questionnaire consisting of 13 statement items. The questionnaire was constructed from Albert Bandura's theory and based on the dimensions of self-efficacy. This questionnaire was adapted from a questionnaire proposed by May (2009). The validity of this questionnaire had been examined using logical validity, namely expert validity, in which the expert was a linguist. In addition to using the logical validity test, this questionnaire was also verified for empirical validity by trailing this questionnaire on batch 2018 students, totalling 83 participants. To measure the validity of this questionnaire, the researchers employed the product-moment correlation technique by utilising SPSS 23.0 software. This questionnaire is declared valid if the value of the correlation coefficient is greater than the value of the $r$-table. Furthermore, in examining the reliability of this questionnaire, researchers applied Cronbach's alpha by utilising SPSS 23.0 software. If the value of Cronbach's alpha is $>0.60$, this questionnaire can be declared reliable. The results of the product-moment correlation indicated that of 13 items, 10 were valid and 3 items were invalid. Meanwhile, the result of Cronbach's alpha analysis indicated a score of 0.716 . Therefore, this questionnaire was considered a valid and reliable instrument.

\subsection{Data analysis}

In this study, researchers carried out two types of analyses: descriptive and inferential analyses. Descriptive analysis was conducted to describe the distribution characteristics of data from two examined variables, namely self-efficacy and numeracy skills.

After that, the researchers applied inferential analysis. In inferential analysis, there are several stages becoming prerequisites, namely data normality testing and data linearity testing. The normality testing was carried out using SPSS 23.0 software with the Kolmogorov-Smirnov method. Meanwhile, the linearity testing was also carried out using SPSS 22, but with the testfor-linearity method set less than 0.05 . Subsequently, researchers conducted hypothesis testing to determine the effect of self-efficacy on numeracy skills using simple linear regression analysis.

At the initial stage, testing was conducted to determine the relationship or correlation between self-efficacy and numeracy. The interpretation for the correlation coefficient value can be seen in Table 2. 
Table 2. Interpretation of the correlation coefficient values

\begin{tabular}{lc}
\hline Value of $R$ & Interpretation \\
\hline $0.800<r_{x y} \leq 1.000$ & Very high \\
$0.600<r_{x y} \leq 0.800$ & High \\
$0.400<r_{x y} \leq 0.600$ & Sufficient \\
$0.200<r_{x y} \leq 0.400$ & Low \\
$0.000<r_{x y} \leq 0.200$ & Very low \\
\hline
\end{tabular}

After that, it was followed by hypothesis testing using a simple linear regression, namely statistical $t$-test. To find out to what extent is the effect of self-efficacy on numeracy skills of prospective elementary school teachers, researchers used the coefficient of determination by utilising SPSS 23.0 software.

\section{Result}

In this study, researchers carried out data analysis to find out to what extent the effect of self-efficacy on numeracy skills of prospective elementary school teachers was. For making this data analysis easier, researchers utilised SPSS 23.0 software.

The purpose of descriptive analysis in this study was to describe the characteristics of respondents based on each research variable, namely self-efficacy $(X)$ and numeracy skills $(Y)$. The outputs of descriptive analysis using SPSS 23.0 software consisted of the minimum score, maximum score, mean, standard deviation and variance. The results of the descriptive analysis concerning numeracy skills can be seen in Table 3.

Table 3. Results of the descriptive analysis on numeracy skills

\begin{tabular}{lccccc}
\hline & & & Maximu & & $\begin{array}{c}\text { Std. } \\
\text { deviation }\end{array}$ \\
& $N$ & Minimum & $\mathrm{m}$ & Mean & 11.119 \\
$\begin{array}{l}\text { Numeracy skills } \\
\begin{array}{l}\text { Valid } N \\
\text { (listwise) }\end{array}\end{array}$ & 293 & 40 & 94 & 73.23 & \\
\hline
\end{tabular}

Based on Table 3, the minimum score in the numeracy test from 293 respondents was 40, while the maximum score was 94. For the mean and variance, they were 73.23 and 11.119, consecutively.

Mathematics' self-efficacy consisted of three dimensions. The first dimension is levelling with indicators of the task difficulty and the behaviour or attitude shown in dealing with tasks. The second dimension is strength with indicators of confidence and individual expectations of abilities possessed. Finally, the third dimension is a generalisation with indicators of not considering experience as an obstacle and making the experience a basis for increasing 
confidence. An overview of the mathematics self-efficacy of prospective elementary school teachers can be seen in Table 4.

Table 4. Distribution of mathematics' self-efficacy of prospective elementary school teachers

\begin{tabular}{lccc}
\hline Intervals & Criteria & Frequency & Percentage \\
\hline$X<25.27$ & High & 33 & 11.26 \\
$25.27 \leq X<34.88$ & Moderate & 200 & 68.25 \\
$34.88 \leq X$ & Low & 60 & 20.47 \\
\hline
\end{tabular}

Table 4 indicates that from 293 respondents, those with high self-efficacy were 33 respondents (11.26\%), those with moderate self-efficacy were 200 respondents $(68.25 \%)$ and those with low self-efficacy were 60 respondents (20.47\%).

The analysis of the effect of self-efficacy on numeracy skills was carried out using a simple linear regression test. The extent of the effect was seen from the magnitude of the coefficient of determination. Before moving to hypothesis testing, researchers conducted a normality test and a linearity test to examine whether the collected data in this study were normally distributed and had a linear relationship.

The analysis for the normality test of data concerning numeracy skills was carried out using the Kolmogorov-Smirnov test by utilising SPSS 23.0 software. The results of the analysis are presented in Table 5.

Table 5. The results of the normality test

\begin{tabular}{lcc}
\hline & & Numeracy skills \\
\hline$N$ & Mean & 293 \\
Normal parameters & & 73.23 \\
& $\begin{array}{c}\text { Std. } \\
\text { deviation }\end{array}$ & 11.119 \\
Most extreme & Absolute & 0.060 \\
differences & Positive & 0.041 \\
& Negative & -0.060 \\
Test statistic & & 0.060 \\
Asymp. Sig. (2-tailed) & & $0.012^{\mathrm{c}}$
\end{tabular}

a Test distribution is normal.

Table 5 shows that the total of respondents was 293; the score for normal parameters was 73.23; and the value of asymp. sig. was 0.012 . This means that the data are normally distributed 
because the value of asymp. sig. is more than 0.05 and so $H_{0}$ is accepted. In other words, the data are normally distributed.

The data concerning numeracy skills were analysed and calculated using SPSS 23.0 software based on the test for linearity. The results of the analysis are presented in Table 6.

Table 6. Results of the linearity test

\begin{tabular}{|c|c|c|c|c|c|c|c|}
\hline & & & $\begin{array}{l}\text { Sum of } \\
\text { squares }\end{array}$ & $d f$ & $\begin{array}{l}\text { Mean } \\
\text { square }\end{array}$ & $F$ & Sig. \\
\hline \multirow[t]{5}{*}{$\begin{array}{l}\text { Numeracy skills } \\
* \text { self-efficacy }\end{array}$} & $\begin{array}{l}\text { Between } \\
\text { groups }\end{array}$ & $\begin{array}{c}\text { (Combined } \\
\text { ) }\end{array}$ & $\begin{array}{c}9,142.64 \\
6\end{array}$ & 20 & 457.132 & 4.612 & 0.000 \\
\hline & & Linearity & $\begin{array}{c}7,239.70 \\
5\end{array}$ & 1 & 7,239.705 & $\begin{array}{c}73.04 \\
4\end{array}$ & 0.000 \\
\hline & & $\begin{array}{c}\text { Deviation } \\
\text { from } \\
\text { linearity }\end{array}$ & $\begin{array}{c}1,902.94 \\
1\end{array}$ & 19 & 100.155 & 1.010 & 0.449 \\
\hline & Within groups & & $\begin{array}{c}26,959.0 \\
33\end{array}$ & 272 & 99.114 & & \\
\hline & Total & & $\begin{array}{c}36,101.6 \\
79\end{array}$ & 292 & & & \\
\hline
\end{tabular}

Based on Table 6, the F-value in the row of deviation from linearity was 1.010 with a significance value of 0.449 . It means that the significance value is $\geq \propto(0.449 \geq 0.05)$. Therefore, $H_{0}$ is accepted. In other words, the data of variable $X$ and variable $Y$ have a linear relationship.

Based on the normality test and linearity test, it can be considered that the obtained data are normal and linear and that simple linear regression analysis can be used in this study. In applying this simple linear regression analysis, researchers used SPSS 23.0 software. The results of this analysis can be seen in Table 7.

Table 7. Output of the simple linear regression analysis

\begin{tabular}{lcccc}
\hline Model & $R$ & $R$ square & $\begin{array}{c}\text { Adjusted } R \\
\text { square }\end{array}$ & $\begin{array}{c}\text { Std. error of } \\
\text { the estimate }\end{array}$ \\
\hline 1 & $0.448^{\mathrm{a}}$ & 0.201 & 0.198 & 9.959
\end{tabular}

a Predictors: (Constant), self-efficacy.

Table 7 shows the summary of the model, such as the value of $R$ indicates a simple correlation between the independent variable and the dependent variable. The interpretation for this value is that if it is closer to 1 , the relationship between variables is getting closer as well. In addition, the value of $R^{2}$ indicates the value of the coefficient of determination. This value is then converted into percentage to determine the influence percentage of the independent variable on the dependent variable. Furthermore, the value of the adjusted $R^{2}$ shows the effect of the 
independent variable on the dependent variable, especially if the independent variable is more than 2.

Table 8. Results of the regression coefficient

Coefficients $^{\mathrm{a}}$

\begin{tabular}{|c|c|c|c|c|c|c|}
\hline \multirow[b]{2}{*}{ Model } & & \multicolumn{2}{|c|}{$\begin{array}{l}\text { Unstandardised } \\
\text { coefficients }\end{array}$} & \multirow{2}{*}{$\begin{array}{c}\text { Standardised } \\
\text { coefficients }\end{array}$} & \multirow[b]{2}{*}{$t$} & \multirow[b]{2}{*}{ Sig. } \\
\hline & & $B$ & Std. error & & & \\
\hline \multirow[t]{2}{*}{1} & (Constant) & 42.066 & 3.694 & & 11.389 & 0.000 \\
\hline & Self-efficacy & 1.036 & 0.121 & 0.448 & 8.544 & 0.000 \\
\hline
\end{tabular}

a Dependent variable: Numeracy skills.

Based on the results of the regression analysis presented in Table 8 , the obtained constant value was 42.066 and the value of the self-efficacy coefficient was 1.036 . From these values, researchers then made the estimated regression function, namely $Y=42.066+1.036 X$. This means that if the value of the variable of self-efficacy increases by 1 unit, the value of the variable of numeracy skills will increase by 1.036 units with a constant value of 42.066 . The visual representation of the effect of self-efficacy on numeracy skills is shown in Figure 2.

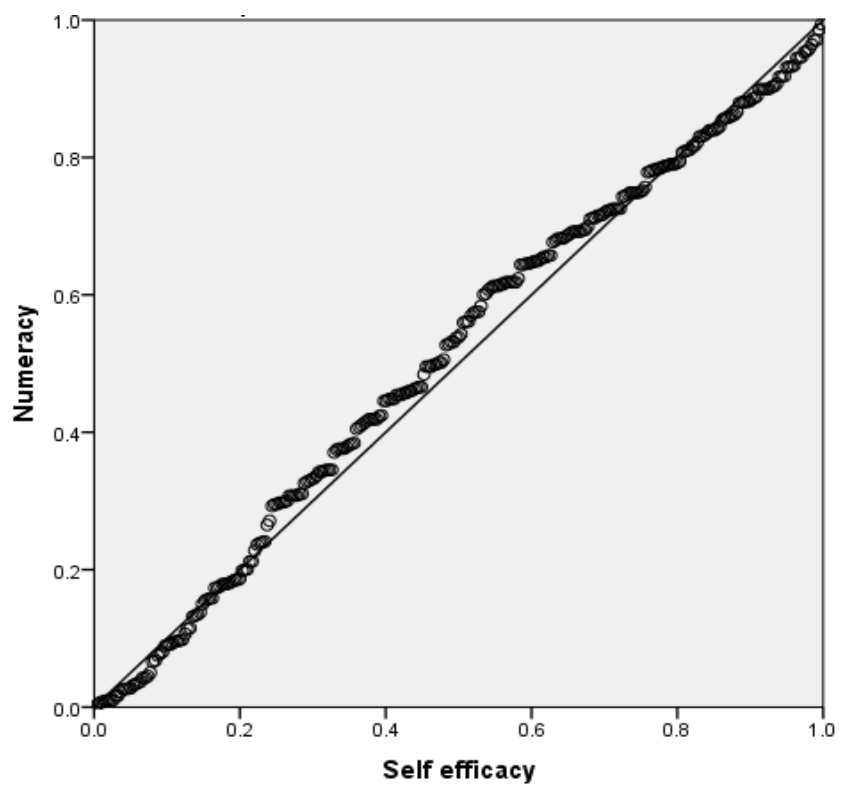

Figure 2. Scatter diagram graph for linear regression 
In addition, the obtained value of asymp. sig. (2-tailed) was 0.000 , with $\alpha=0.05$. Therefore, because 0.000 is $<0.05, H_{0}$ is rejected, meaning that self-efficacy has a significant positive effect on the numeracy skills of prospective elementary school teachers.

In this study, researchers applied the product-moment correlation to determine the relationship between two variables. The results of the correlation analysis can be seen in the results of the simple regression analysis presented in Table 7 . The results of the calculation in Table 7 show that the value of $R$ was 0.448 . It indicated that the correlation was classified in the moderate category.

To find out to what extent the effect of self-efficacy on numeracy skills of prospective elementary school teachers is, researchers used the coefficient of determination by utilising SPSS 23.0 software. The results of the coefficient of determination are presented in Table 9.

Table 9. Results of the coefficient of determination

\begin{tabular}{lcccc}
\hline Model & $R$ & $R$ square & $\begin{array}{c}\text { Adjusted } R \\
\text { square }\end{array}$ & $\begin{array}{c}\text { Std. error of } \\
\text { the estimate }\end{array}$ \\
\hline 1 & $0.448^{\mathrm{a}}$ & 0.201 & 0.198 & 9.959
\end{tabular}

a Predictors: (Constant), self-efficacy.

By considering the values presented in Table 9, the extent of the effect of self-efficacy on numeracy skills of prospective elementary school teachers can be seen from the value of $R^{2}$, namely 0.201 . In other words, the extent of the effect of self-efficacy on numeracy skills is $20.1 \%$.

\section{Discussion}

The results of the descriptive analysis of the numeracy skills possessed by prospective elementary school teachers in universities throughout Surabaya showed that the average score was 73.23. In addition, the minimum score for the numeracy test from 293 respondents was 40, while the maximum score was 94 . From the results of the analysis of the self-efficacy questionnaire for prospective elementary school teachers in universities throughout Surabaya, it was found out that $11.26 \%$ of the respondents were classified as having high self-efficacy, $68.25 \%$ of them were classified as having moderate self-efficacy and $20.47 \%$ of them were classified as having low self-efficacy.

This study shows that self-efficacy has a positive effect on the numeracy skills of prospective elementary school teachers. The form of the effect of self-efficacy on numeracy skills is a positive effect, which is indicated by the positive regression value. Therefore, it can be concluded that if the value of the variable of self-efficacy increases, the value of the variable of numeracy skills of prospective elementary school teachers will increase as well. Conversely, if the value of the variable of self-efficacy decreases, the value of the variable of numeracy skills of prospective elementary school teachers will decrease as well. Furthermore, the estimated regression function is $Y=42.066+1.036 X$, indicating that if the value of the variable of selfefficacy increases by 1 unit, the value of the variable of numeracy skills will increase by 1.036 units with a constant value of 42.066 . 
Via, Y., Tatag, S., \& Abadi, A., (2021). The effect of mathematics self-efficacy on numeracy skills of prospective elementary school teachers. Cypriot Journal of Educational Science. 16(6), 3394-3406 https://doi.org/10.18844/cjes.v16i6.6590

In the statistical test examining the effect of self-efficacy on numeracy skills, researchers applied a simple regression analysis, resulting in the coefficient of determination of $20.1 \%$. This means that $20.1 \%$ of the contribution to the numeration skills of prospective elementary school teachers is influenced by self-efficacy, while the remaining $79.9 \%$ is influenced by other factors not examined in this study. This is supported by the results of a study conducted by Cheema (2018), which showed that self-efficacy affected the mathematical literacy of high school students in Greece with a contribution of 38\%. This effect persisted even after controlling for differences in student-related factor levels, such as age, grade, gender, parents' educational levels, parents' occupation, family wealth, post-cultural sessions, availability of educational resources at home and school-level differences.

Self-efficacy is one of the factors that influence mathematics learning achievement. In addition, self-efficacy can be considered as self-confidence obtained from an individual's mentality and cognitive reception of reality, which is established by past and present experiences and stored in the memory (Zimmerman, 2010). Therefore, those who possess high self-efficacy believe that they can carry out the activities that should be carried out. On the other hand, those who possess low self-efficacy can be unsure about their ability to carry out an activity, leading to a greater affect in learning achievement. This is in line with the argument put forward by Roberts and Hogan (2001) that those having high self-efficacy tend to expend more effort and persist in a task because they have the belief that they will succeed in achieving goals and vice versa. Furthermore, students with high self-efficacy may always feel optimistic in achieving the learning goals that they have set. For this reason, they may apply independent learning as an effort to encourage themselves to solve numeracy problems. Based on this elaboration, the affective aspects, including self-efficacy, play an important role in supporting the success of the cognitive aspect, namely numeracy skills.

The results of a study conducted by Cheema (2018) indicated that self-efficacy affects learning achievement in mathematics, in which the improvement and optimisation of student learning achievement can be realised by increasing students' self-efficacy. Furthermore, to improve self-efficacy, students need to be supported by improving relationships with teachers, peers, family and the environment. The results of this study are also in line with the argument put forward by Yildiz et al. (2019) that achievements in the past are performance experiences. This means that good achievements may increase self-efficacy expectations, while failure may reduce self-efficacy.

\section{Conclusion}

Based on the results and discussion, it can be concluded that self-efficacy has a positive effect on the numeracy skills of prospective elementary school teachers. The extent of the effect of self-efficacy on numeracy was only $20.1 \%$. This indicates that the numeracy of prospective elementary school teachers is influenced by other factors that are not examined in this study. This study provides information on the characteristics and patterns of the relationship between self-efficacy and numeracy skills of elementary school teachers. 
Via, Y., Tatag, S., \& Abadi, A., (2021). The effect of mathematics self-efficacy on numeracy skills of prospective elementary school teachers. Cypriot Journal of Educational Science. 16(6), 3394-3406 https://doi.org/10.18844/cjes.v16i6.6590

\section{Suggestions}

Based on the discussion and conclusion, researchers suggest that self-efficacy needs to be considered as a supporting factor for the success of solving numeracy problems.

\section{Acknowledgements}

The authors would like to thank the rector of Universitas Negeri Surabaya and the Ministry of Education, Culture Research and Technology (Kemdikbudristek) for supporting this research through grant funding the 'Skim Hibah Disertasi Doctor' programme with the main contract number 167/E4.1/AK.04.PT/2021 and derivative contracts 038/AMD-SP2H/LT-MULTIPDPK/LL7/2021.

\section{References}

Arslan, C., \& Yavuz, G. (2012). A study on mathematical literacy self-efficacy beliefs of prospective teachers. Procedia - Social and Behavioral Sciences, 46, 5622-5625. https://doi.org/10.1016/j.sbspro.2012.06.484

Blomeke, S., Kaiser, G., Konig, J., \& Jentsch, A. (2020). Profiles of mathematics teachers' competence and their relation to instructional quality. ZDM - Mathematics Education, 52(2), 329-342. https://doi.org/10.1007/s11858-020-01128-y

Callingham, R., Beswick, K., \& Ferme, E. (2015). An initial exploration of teachers' numeracy in the context of professional capital. ZDM - International Journal on Mathematics Education, 47(4), 549-560. https://doi.org/10.1007/s11858-015-0666-7

Cassen, R., McNally, S., Vignoles, A., \& McNally, S. (2018). Numeracy and mathematics. In Making a difference in education (vol. 48, pp. 123-133). https://doi.org/10.4324/9781315712352-8

Cheema, J. R. (2018). Effect of math-specific self-efficacy on math literacy: Evidence from a Greek survey. Research in Education, 102(1), 13-36. https://doi.org/10.1177/0034523717741914

Creswell, J. W. (2012). Educational research: Planning, conducting, and evaluating quantitative and qualitative research (4th ed.). Pearson. inc.

Garvis, S., \& Pendergast, D. (2016). Asia-Pacific perspectives on teacher self-efficacy. https://doi.org/10.1007/97894-6300-521-0

Gerde, H. K., Pierce, S. J., Lee, K., \& Van Egeren, L. A. (2018). Early childhood educators' self-efficacy in science, math, and literacy instruction and science practice in the classroom. Early Education and Development, 29(1), 70-90. https://doi.org/10.1080/10409289.2017.1360127

Ghazali, M. (2020). Numeracy and the education value chain. In W. Leal Filho, A. Azul, L. Brandli, P. Ozuyar, \& T. Wall (Eds.), Quality education. https://doi.org/10.1007/978-3-319-69902-8_86-1

Lange, J. D. (2003). Mathematics for literacy.

Maher, C. A., Sigley, R., \& Brunswick, N. (2014). Encyclopedia of mathematics education. In Encyclopedia of mathematics education. https://doi.org/10.1007/978-94-007-4978-8

Mahmud, M. R., \& Pratiwi, I. M. (2019). Literasi Numerasi Siswa Dalam Pemecahan Masalah Tidak Terstruktur. KALAMATIKA Jurnal Pendidikan Matematika, 4(1), 69-88. https://doi.org/10.22236/kalamatika.vol4no1.2019pp69-88

May, D. K. (2009). Mathematics self-efficacy and anxiety questionnaire (pp. 1-93).

Millet, A., Brown, M., \& Askew, M. (2004). Primary mathematics and the developing professional (vol. 1). 
Via, Y., Tatag, S., \& Abadi, A., (2021). The effect of mathematics self-efficacy on numeracy skills of prospective elementary school teachers.

Cypriot Journal of Educational Science. 16(6), 3394-3406 https://doi.org/10.18844/cjes.v16i6.6590

https://doi.org/10.1007/1-4020-1915-7

Nahdi, D. S., Jatisunda, M. G., Cahyaningsih, U., \& Suciawati, V. (2020). Pre-service teacher's ability in solving mathematics problem viewed from numeracy literacy skills. Elementary Education Online, 19(4), $1902-1910$. https://doi.org/10.17051/ilkonline.2020.762541

OECD. (2019). The survey of adult skills : Reader's companion. In OECD skills studies (3rd ed.). https://www.oecdilibrary.org/education/the-survey-of-adult-skills_f70238c7-en

Ozgen, K. (2013). Self-efficacy beliefs in mathematical literacy and connections between mathematics and real world: The case of high school students. Journal of International Education Research (JIER), 9(4), 305-316. https://doi.org/10.19030/jier.v9i4.8082

Roberts, B. W., \& Hogan, R. (2001). Personality psychology in the workplace. In American Psychological Association. https://doi.org/10.1017/CBO9781107415324.004

Robson, E. (2010). Numeracy. The Princeton Companion to Mathematics, $27(2), 983-991$. https://doi.org/10.7326/0003-4819-128-9-199805010-00030

Sellars, M. (2018). Numeracy in authentic contexts. https://doi.org/10.1007/978-981-10-5736-6

Skaalvik, E. M., Federici, R. A., \& Klassen, R. M. (2015). Mathematics achievement and self-efficacy: Relations with motivation for mathematics. International Journal of Educational Research, 72, $129-136$. https://doi.org/10.1016/j.ijer.2015.06.008

Steen, L. A. (2003). Data, shapes, symbols: Achieving balance in school mathematics. Evolution of Numeracy and the National Numeracy Network, (Hammond 1978), 53-74.

Tariq, V. N., Qualter, P., Roberts, S., Appleby, Y., \& Barnes, L. (2013). Mathematical literacy in undergraduates: Role of gender, emotional intelligence and emotional self-efficacy. International Journal of Mathematical Education in Science and Technology, 44(8), 1143-1159. https://doi.org/10.1080/0020739X.2013.770087

Yildiz, P., Ciftci, S. K., \& Ozdemir, I. E. Y. (2019). Mathematics self-efficacy beliefs and sources of self-efficacy: A descriptive study with two elementary school students. International Journal of Progressive Education, 15(3), 194-206. https://doi.org/10.29329/ijpe.2019.193.14

Yustitia, V., Siswono, T. Y. E., \& Abadi. (2021). Numeracy of prospective elementary school teachers: A case study. Journal of Physics: Conference Series, 1918(4). https://doi.org/10.1088/1742-6596/1918/4/042077

Zhu, J., \& Chiu, M. M. (2019). Early home numeracy activities and later mathematics achievement: Early numeracy, interest, and self-efficacy as mediators. Educational Studies in Mathematics, 102(2), $173-191$. https://doi.org/10.1007/s10649-019-09906-6

Zimmerman, B. J. (2010). Self-efficacy and educational development. In Self-Efficacy in changing societies. https://doi.org/10.1017/cbo9780511527692.009 